\title{
Rice Harvest in Ceylon
}

\section{R. J. Drummond}

To cite this article: R. J. Drummond (1902) Rice Harvest in Ceylon, Folklore, 13:3, 277-278, DOI: 10.1080/0015587X.1902.9719311

To link to this article: http://dx.doi.org/10.1080/0015587X.1902.9719311

$$
\text { 曲 Published online: } 06 \text { Feb } 2012 .
$$

5 Submit your article to this journal $₫$

Џll Article views: 1

Q View related articles ¿ 
Mr. W. G. Aston, whom I have consulted upon this custom, kindly refers me to a quotation by him, in a note to his translation of the Nihongi (London, Japan Society, 1896), vol. ii., p. I 50, of the description of the practice in Yamada's Japanese Dictionary. The practice is called Nagare-Kanjo (Kanjö meaning baptism, or head-sprinkling), and is thus described : "Four posts are set up near water, on which white cloth is hung. To this are attached leaves of lign-aloes, \&c., as offerings for the benefit of the souls of the friendless dead, of drowned persons, or of women who have died in childbirth." Mr. Aston informs me that the expression here given as "women who have died in childbirth" is ambiguous in the original, and may mean "still-born children"; and by an accident he so rendered it in the Nihongi. He is satisfied, however, that "women who have died in childbirth" is intended. He also informs me that another Japanese authority states that the four pillars on which the cloth rests are, or represent, sotoba, i.e., the commemorative laths or posts, inscribed with Sanskrit characters, which are set up at graves. The practice, he adds, has been described in Our Neighbourhood, by T. A. P. (the late Dr. Purcell, of Tokio), a wark subsequently republished in London under the title of $A$ Suburb of Yedo.

E. S. Hartland.

\section{Rice Harvest in Cenlon. \\ (Communicated by Mr. J. G. FrazER.) \\ (Supra, p. 77.)}

On an estate in Ceylon near here, in February, the Tamil coolies (Hindus) drowned the god Madu Sami in the river. For three days he was drowned, and during that time Mooniandi the devil reigned supreme. The men got sticks and beat the women, calling out, "You have the devil in you!" and chasing them all over the estate. Then they fixed on one old woman, beat her, made her carry a large stone on her head, and made her run three times round the coolie-houses. Then they threw stones and chased her to the Mocniandi Sami stone, and there they had incantations; and pushing her to a tree, near the Mooniandi 
shrine, nailed her hair to the tree, and then cut it from her head. The woman was free then, and the hair remained there. On the third day they resurrected the Madu Sami doll, and peace reigned as before. This was done after the rice-harvest was over. Mooniandi Sami is always propitiated by a sacrifice or thank-offering or scapegoat. They say : "Here, devil, is your pottion, or sacrifice, now leave us alone, you have had your share."

$$
\begin{aligned}
& \text { Belgravia, Talawakelle, } \\
& \text { 23rd March, I902. }
\end{aligned}
$$

R. J. DRUmmond.

\section{UnluCky AND JuCky ChILdREN, AND SOME BIRTH SUPERSTITIONS.}

$$
\text { (Supra, pp. 63, 188, 197.) }
$$

Tre Frrst-Born.-In the Punjab the first-born son of a wife is peculiarly uncanny, especially subject to magical influences and endowed with supernatural powers. On the one hand his hair is useful in witchcraft, and on the other its possession would give a wizard power over him. He himself possesses considerable magical powers, for he can stop hail by throwing a stone backwards from, or by cutting a hailstone with, a knife; and he can stay a dust storm by standing naked in front of it. He is also peculiarly subject to lightning, and is not allowed to go out on a rainy day. Snakes also become torpid in his presence. (Fuller notes on this or similar ideas would be welcome.)

A first-born child, whether a boy or a girl, should not bo married in Jeth ${ }^{2}$ (or, one account adds, in Măgh), nor should the mother eat first-fruits in that month, because as she devours them so too will the fates devour her first-born. The position of the first-born is probably due to the fact that, if a son, his father is born again in him, so that the father is supposed to die at his

1 But according to tho Matha.KTatra Cranth, sloka 15 , of Bhardwaj Rikhl, It is only necessary to avoid marriage in Jeth, if both parties be Jethas, ie., horn in Jeth, or if it is not possible to avold Jeth the ceremony should not be held in the Kirt Nackshatra during that month. 